\title{
National Sentiment: Nation Building and Emotional Language in Nineteenth- Century Finland
}

\author{
Jani Marjanen
}

\section{INTRODUCTION}

During the course of the late eighteenth century and the early nineteenth century, the term national sentiment was coined and established in several European languages. Translations vary and carry slightly different connotations, but there are clear similarities in how national sentiment in English, Nationalgefübl in German, sentiment national in French, nationalkänsla in Swedish, and kansallistunne in Finnish were used and developed.

This work has been supported by the European Union Horizon 2020 research and innovation program under grant 770299 (NewsEye) and the Academy of Finland under grant 324778 .

J. Marjanen $(凹)$

University of Helsinki, Helsinki, Finland

e-mail: jani.marjanen@helsinki.fi

(C) The Author(s) 2021

V. Kivimäki et al. (eds.), Lived Nation as the History of Experiences and Emotions in Finland, 1800-2000, Palgrave Studies in the History of Experience, https://doi.org/10.1007/978-3-030-69882-9_3 
The emergence of the term in several different languages at roughly the same time is indicative of changes both in the language of nationhood and emotion. At this time, more and more things were conceived of as being national. Terms like national economy, national literature, national history, or national anthem were coined and lexicalized, indicating the breakthrough of a national perspective on understanding society. State institutions were gradually understood as national institutions. ${ }^{1}$ Similarly, language relating to feelings, passions, sentiments, and emotions underwent a change. In the eighteenth century, passions and feelings were largely regarded as things that were evoked by outer impulses and needed to be controlled. Toward the end of the nineteenth century the understanding of them became more narrowly understood and psychological. In this process the words emotion in English and Gefühl in German started dominating the emotional vocabulary. In this new, more scientific approach, outer impulses were still important, but, deep down, emotions were internal, related primarily to the self, and could be understood through psychological scrutiny. ${ }^{2}$

The concept of national sentiment was located in the intersection of these two developments, as it is part of the expanding national perspective and the narrower descriptions of emotional experience. But, the term's gradual decline in the late nineteenth century and early twentieth century also relates to the changes in the two vocabularies, making national sentiment, if not an ephemeral concept, one that had to adapt to a world in which emotions were more likely to be understood as psychological and in which national belonging was seen as less voluntarist. This chapter charts this development as it took place in the context of Finland by exploring the language of national sentiment in nineteenth-century newspapers. In the Finnish case, nineteenth-century nation building is characterized as a particularly quick and conscious process as Finland belongs to the socalled young nations, that is, it was one of the imperial substructures in

\footnotetext{
${ }^{1}$ Simon Hengchen et al., "A Data-Driven Approach to Studying Changing Vocabularies in Historical Newspaper Collections," Digital Scholarship in the Humanities, n.d., https://doi. org/10.1093/llc/fqab032; Benedict Anderson, Imagined Communities: Reflections on the Origin and Spread of Nationalism, rev. ed. (London: Verso, 2006 [1983]); Joep Leerssen, National Thought in Europe: A Cultural History, lst ed. (Amsterdam: Amsterdam University Press, 2006), 15.

${ }^{2}$ Ute Frevert et al., Gefühlswissen: Eine lexikalische Spurensuche in der Moderne, lst ed. (Frankfurt am Main: Campus Verlag, 2011); Thomas Dixon, “'Emotion': The History of a Keyword in Crisis," Emotion Review 4:4 (2012), 338-44, https://doi. org/10.1177/1754073912445814
} 
which the post-Napoleonic period quite abruptly presented local elites the possibility of developing a nationhood and statehood. Once that development caught on with non-elite communities, nation building soon cemented a new societal order.

Although most modern scholars of Finnish nation building acknowledge the role of emotional attachment as being part of a so-called national awakening, this perspective has seldom led to a focus on past language, ${ }^{3}$ and even then the focus has not been on the concrete emotional vocabulary but rather on creating a typology of very broadly defined discourses. The starting point of this chapter is the notion of past language serving as a source to understanding past experiences of people as well as their expectations and desires for the future. ${ }^{4}$ Texts that talk about national sentiment are instances in which some of the past experiences recorded in language are revealed to us if we interrogate the changing meanings of the term. Talking or writing about it was a way of setting the frame for how people could think about feelings for and in the nation. But texts including the term could also portray innovative speech acts that challenged prevalent meanings of national sentiment in a given time. They were also ways to probe new methods of experiencing, so to speak testing, to what degree it could make sense to talk about things national and feelings in the same expression. In particular, early uses of the term should be seen as partly programmatic and partly experimental.

National sentiment has not been at the heart of the history of emotions because it is perhaps hard to conceive of what kind of emotion, if any, we are talking about. However, there are good reasons to argue that precisely therefore it serves as a good case for criticizing a universalizing approach to the emotions that assumes emotions to be unchanging units that can be separated from the words, gestures, or other expressions describing them. ${ }^{5}$ Rather, the language relating to emotions ought to be seen as part of the expressional repertoires, which reflect and shape emotional experiences. Talking about emotions or coupling other things with the language of emotions (like in the term national sentiment), is here seen as an emotional

\footnotetext{
${ }^{3}$ Päivi Rantanen, Suolatut säkeet: Suomen ja suomalaisten diskursiivinen muotoutuminen 1600-luvulta Topeliukseen (Helsinki: SKS, 1997).

${ }^{4}$ Reinhart Koselleck, Vergangene Zukunft: Zur Semantik geschichtlicher Zeiten (Frankfurt am Main: Suhrkamp, 1979), 349-75; Reinhart Koselleck, "Einleitung," in Geschichtliche Grundbegriffe: Historisches Lexikon zur politisch-sozialen Sprache in Deutschland, ed. by Reinhart Koselleck, Otto Brunner \& Werner Conze (Stuttgart: E. Klett, 1972), XIII-XXV.

${ }^{5}$ For such a critical approach, see Rob Boddice, The History of Emotions (Manchester: Manchester University Press, 2018).
} 
practice that is historically situated. ${ }^{6}$ Taking stock of discourse as emotional practice thus questions the notion of real emotions versus the language of emotion, even with regard to emotions that are often seen as fundamental to being human, like fear. ${ }^{7}$ According to this perspective, fear is lived out through emotional practices in different culturally constructed settings and those practices form the scripts for how to live out fear and how to challenge earlier performances of it. ${ }^{8}$ This does not mean that the experience of fear and the performance of that emotion is not real to people, it is just making the claim that there is no single experience of fear that people feel universally, but only culturally mediated scripts that make experiences of fear mutually intelligible. Linguistic expressions are one of the most common ways of communicating those experiences, even if they are not the only ones and remain imprecise.

Studying national sentiment differs from looking into historical experiences and performances of fear, because the discourse of national sentiment generally takes a step away from emotional experience. A feeling toward the nation can be about actual feelings in the sense that individuals would express this devotion through the language of national sentiment. However, statements about national sentiment are usually not about actual feelings but work on a meta level as reflections about the role of emotions in politics, society, and culture. This level of abstraction makes the discourse concerning national sentiment a sign of an evolving emotional vocabulary. Hence, this chapter studies linguistic expressions as a way of seeing to which degree, by whom, and why it made sense to talk about national sentiment, despite the fact that historical actors did mean different things by it. My survey shows that authors could talk about national sentiment by referring to at least four different meaningsnational sentiment as devotion toward the nation, as a characteristic of the people, as a description of the atmosphere in the country, and as the collective self-esteem of the country. By tracing these uses, this chapter advances the argument that the discourse moved from highlighting a romantic and personalized relationship to nation building as a necessary

\footnotetext{
${ }^{6}$ Monique Scheer, "Are Emotions a Kind of Practice (and Is That What Makes Them Have a History)? A Bourdieuian Approach to Understanding Emotion," History and Theory 51:2 (2012), 193-220, https://doi.org/10.1111/j.1468-2303.2012.00621.x

${ }^{7}$ For an overview and discussion on how fear has been approached, see Margrit Pernau, "What Object Is Fear?" History and Theory 54:1 (2015), 86-95, https://doi.org/10.1111/ hith.10742

${ }^{8}$ For an overview of "emotional scripts," see Jonathan H. Turner \& Jan E. Stets, "Sociological Theories of Human Emotions," Annual Review of Sociology 32:1 (2006), 26-8, https://doi.org/10.1146/annurev.soc.32.061604.123130
} 
step in self-fulfillment in the early nineteenth century to a description of collective emotional experiences in the latter half of the century. It further suggests that the frame of experiencing national belonging changed. The voluntarist (perhaps even constructivist) notion of nationhood was surpassed by a collective and naturalized notion of feeling about the nation. As a part of this development, national sentiment became more often characterized as a sort of collective emotion. ${ }^{9}$ It seems, however, that it did not fit well in the context of the intensified nationalism of the last decades of the nineteenth century and first half of the twentieth century, and was at least partly replaced by the less flexible category of national character. ${ }^{10}$

Through the example of national sentiment, this chapter also tries to underline the need to find new ways to study nation building as a process in which emotions are present. Although there are quite a few texts that explore what the word "love" in "love of country" means or how emotions have been key elements in the rise of patriotism, nationalism, and populism, ${ }^{11}$ the means of concretely studying the expressions that relate to emotions, are not fully explored. Because it is unclear what kind of feelings were really at stake when nineteenth-century authors talked about national sentiment, this chapter highlights the need to take stock of concrete historical instances in which historical actors talked about emotions in conjunction with the nation. While there are plenty of studies highlighting the role of emotions as a part of nation building, ${ }^{12}$ there are fewer studies that trace how historical actors themselves made this connection.

\section{National Sentiment and Newspapers}

The focus on language relating to emotions presents a challenge in choosing the right sources. Printed material has not been seen as the best source for the history of emotions, which has rather deployed ego documents for

\footnotetext{
${ }^{9}$ Christian von Scheve \& Sven Ismer, "Towards a Theory of Collective Emotions," Emotion Review 5:4 (2013), 406-13, https://doi.org/10.1177/1754073913484170

${ }^{10}$ See Balázs Trencsényi, The Politics of "National Character": A Study in Interwar East European Thought (New York: Routledge, 2011), 12.

${ }^{11}$ Maurizio Viroli, For Love of Country: An Essay on Patriotism and Nationalism (Oxford: Clarendon Press, 1995); Martha Craven Nussbaum \& Joshua Cohen, For Love of Country? (Boston: Beacon Press, 2002).

${ }^{12}$ For an overview, see Jonathan Heaney, "Emotions and Nationalism: A Reappraisal," in Emotions in Politics, ed. by Nicolas Demertzis (London: Palgrave Macmillan, 2013), 243-63, https://doi.org/10.1057/9781137025661_13
} 
the analysis of more private expressions of emotion. However, for the purpose of studying changing notions of national sentiment, printed sources provide a better entry point as they capture publicly negotiated meanings of terms. ${ }^{13}$ I use nineteenth-century newspapers from Finland as they provide a very large data set covering a variety of historical linguistic expressions and hence also include a wide range of emotional vocabulary. Perhaps more importantly, nineteenth-century newspapers were crucial outlets for different visions of nation building, so discourses of national sentiment were part of the series of disagreements about which things were important for experiencing the nation. ${ }^{14}$ Obviously, newspapers did not cover everything and censorship and limits to what was socially appropriate clearly limit what can be found in the material, but precisely for this reason they are a good source for studying what was regarded as appropriate discourse when it comes to emotions and nationhood. ${ }^{15}$ In general, talking about national sentiment does not seem to have involved using terminology that would have challenged the limits of decency or political appropriateness.

The collection of Finnish digitized newspapers provides a searchable data set for both quantitative analyses of word use as well as for retrieving text passages with key terms. The collection contains all newspapers printed in Finland prior to 1918, but does exclude handwritten papers and some newspaper-like journals. ${ }^{16}$ The material is available as downloadable data packages, but is also accessible through two graphical search interfaces. ${ }^{17}$ Newspaper publishing was rather modest in the early decades of the

${ }^{13}$ For an example of using newspapers, see Nicole Eustace, Passion Is the Gale: Emotion, Power, and the Coming of the American Revolution (Chapel Hill: University of North Carolina Press, 2008), 3-15; For the role of discourse and emotions, see Lila Abu-Lughod \& Catherine Lutz, "Introduction: Emotion, Discourse, and the Politics of Everyday Life," in Language and the Politics of Emotions, ed. by Lila Abu-Lughod \& Catherine Lutz (Cambridge: Cambridge University Press, 2008).

${ }^{14}$ The most famous explication of this argument is in Anderson (2006 [1983]).

${ }^{15}$ Lars Björne, Fribetens gränser: Yttrandefribeten i Norden 1815-1914 (Oslo: Akademisk publisering, 2018); Jani Marjanen, "Gränserna för det offentliga samtalet i Finland 1809-1863," in Offentlighet og yttringsfribet $i$ Norden, ed. by Ruth Hemstad \& Dag Michalsen (Oslo: Pax Forlag, 2019); Pirkko Leino-Kaukiainen, Sensuuri ja sanomalehdistö Suomessa vuosina 1891-1905 (Helsinki: Suomen historiallinen seura, 1984).

${ }^{16}$ Tuula Pääkkönen et al., "Exporting Finnish Digitized Historical Newspaper Contents for Offline Use," D-Lib Magazine 22:7-8 (2016), https://doi.org/10.1045/ july2016-paakkonen

${ }^{17}$ The interfaces can be found here: https://korp.csc.fi and https://digi.kansalliskirjasto. fi/ with better coverage for the twentieth century in the latter. Any newspaper articles cited 
nineteenth century and grew almost exponentially up to the end of the century. In the Finnish case, papers were published in Swedish and Finnish as the main languages, with Swedish-language publications dominating in the early century and Finnish-language output catching up and by the 1890s finally surpassing Swedish-language publications in the amount of words published per year. Smaller amounts of newspapers were also published in German and in Russian. ${ }^{18}$

The asymmetrical relationship between the languages thus changed during the course of the century. Swedish as the language of administration, educated life, and high culture, was gradually challenged by Finnish as the first language of the majority of the population. In addition, Russian, as the main language of the empire, became more important, but knowledge of Russian remained rather limited in Finland, and the influence of Russian when it comes to emotional language remains low, although there are indications that it affected the socialist language of peoplehood in the period around World War I. ${ }^{19}$ The interplay between these three languages was a crucial part of the main political tensions in the country, especially in the latter half of the century.

Focusing on Finnish and Swedish, it is crucial to note that the different language spheres ought not to be seen as separate since most authors and many of the readers had to cope with both languages. Whatever happened in Swedish was recorded in Finnish, and once Finnish became gradually more elevated as a literary language, this also occurred the other way around. Early in the nineteenth century, Swedish and Finnish were separated according to domains of life. Anyone with Finnish as their first language would learn Swedish if pursuing an academic career or aiming for a higher position in society. Finnish did not yet possess the vocabulary for politics and science, but this changed very rapidly. ${ }^{20}$ The expansion of

can be found through both or one if these interfaces and references are given to the title and date of the newspaper. Any statistics are based on the former interface. If I know the author of a text, that is mentioned in the text.

${ }^{18}$ Jani Marjanen et al., "A National Public Sphere? Analyzing the Language, Location, and Form of Newspapers in Finland, 1771-1917," Journal of European Periodical Studies 4:1 (2019), 54-77, https://doi.org/10.21825/jeps.v4il.10483

${ }^{19}$ Max Engman, Språkfrågan: Finlandssvenskhetens uppkomst 1812-1922 (Helsingfors: Svenska litteratursällskapet i Finland, 2016); Pasi Ihalainen, The Springs of Democracy: National and Transnational Debates on Constitutional Reform in the British, German, Swedish and Finnish Parliaments, 1917-1919 (Helsinki: Finnish Literature Society, 2017), 197-205, https://doi.org/10.21435/sfh.24

${ }^{20}$ Katja Huumo, Lea Laitinen \& Outi Paloposki, eds, Yhteistä kieltä tekemässä: Näkökulmia suomen kirjakielen kehitykseen 1800-luvulla (Helsinki: SKS, 2004). 
Finnish as a language of written culture created space for including quite a few more people in the public discourse, many of whom operated only in Finnish. ${ }^{21}$ In this process, Finnish was elevated and made into a language that could be chosen to emphasize one's Finnishness. In the first half of the century, Finnish authors identified as Finns regardless of language, but toward the end of the century language became an issue of identification. Once Finnish started dominating, the minority label Finland-Swede (finlandssvensk) entered the vocabulary to mark Swedish speakers as threatened by the majority - a constellation that would have been impossible in the first decades of the century. ${ }^{22}$ In the final decades of the nineteenth century and the early twentieth century, the Finnish public sphere developed a sort of parallelization of newspapers, cultural institutions, associational life, and political mobilization in which institutions had separate organizations using either Finnish or Swedish. ${ }^{23}$

Because of the shared public sphere and constant translation, the Swedish-language and Finnish-language terms, nationalkänsla and kansallistunne were to a certain degree in sync in Finland. But the languages provided different possibilities for innovation, of course. In Finnish, especially the nearby word kansallistunto (national sentiment or national esteem) was often used in situations where nationalkänsla would have been used in Swedish. None of these words are particularly frequent in the data set. Nationalkänsla occurs in different inflections 1.2 times per one million words in the period before 1920 (with 3912 total hits). For kansallistunne and kansallistunto the same figures are 1.5 (5540) and 2.3 (8642). The figures rely on the optical character recognition used in establishing the machine-readable versions of the newspapers, which is not flawless, so the figures are in reality a bit higher, but can be used as indicators for first uses and when the terms became more common (Fig. 3.1).

A relative frequency graph over time also suggests that once the terms were introduced, they remained in relatively stable use and at quite modest levels. ${ }^{24}$ In Swedish, the word was introduced in the early 1820 s as a

${ }^{21}$ Heikki Kokko, "Suomenkielisen julkisuuden nousu 1850-luvulla ja sen yhteiskunnallinen merkitys," Historiallinen Aikakauskirja 117:1 (2019), 5-21.

${ }^{22}$ Marjanen et al. (2019); Engman (2016).

${ }^{23}$ Päiviö Tommila, Lars-Folke Landgrén \& Pirkko Leino-Kaukiainen, Suomen lebdistön historia 1: Sanomalehdistön vaiheet vuoteen 1905 (Kuopio: Kustannuskiila, 1988); Marjanen et al. (2019); Engman (2016).

${ }^{24}$ The graph is produced using the Korp interface made available by the Language Bank of Finland. Lars Borin, Markus Forsberg \& Johan Roxendal, “Korp - the Corpus Infrastructure 


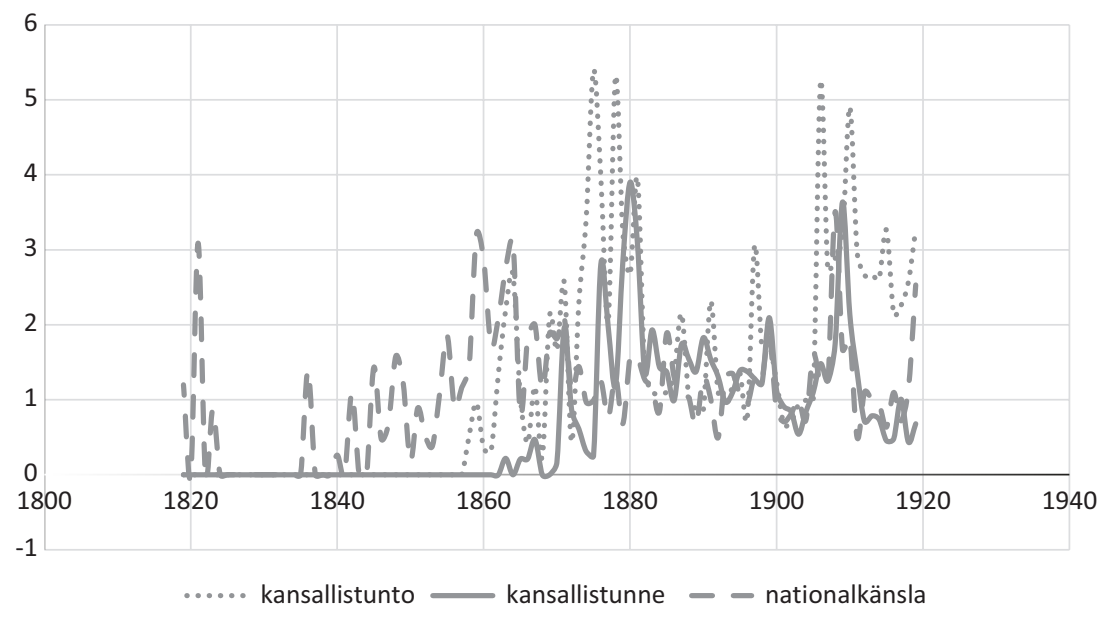

Fig. 3.1 Relative frequency (occurrences per one million words in the data) of nationalkänsla, kansallistunne, and kansallistunto, 1819-1919

part of the so-called Turku romanticism and papers associated with it, but seems to have been adopted more generally only in the 1830s-1840s. For Finnish, the introduction relates to the expansion of the Finnish-language press both in issues and in topics that were dealt with from the $1860 \mathrm{~s}$ onwards. The increase in frequency in the 1870s suggests that the intensified mobilization for the Finnish language also boosted the use of kansallistunto and kansallistunne, but all in all, the relative frequencies do not point to the terms being heavily politicized or going through a semantic shift, but, rather, a steady use once the terms had entered the lexicon. The same goes for the related but less frequent Swedish term nationalanda (national spirit) that was important to some early nineteenth-century authors and is close in meaning to "national sentiment." Graphs produced for English, German, and French in the Google Books data sets provide similar results for the terms national sentiment, Nationalgefühl, and sentiment national and show that the term was already used toward the end of the eighteenth century, but became more commonly employed only in the nineteenth century. ${ }^{25}$ The Google Books data suggest that national

of Språkbanken," in Proceedings of LREC 2012. vol. Accepted (Istanbul: ELRA, 2012), 474-8.

${ }^{25}$ Jean-Baptiste Michel et al., "Quantitative Analysis of Culture Using Millions of Digitized Books," Science 331:6014 (2011), 176-82, https://doi.org/10.1126/science.1199644 


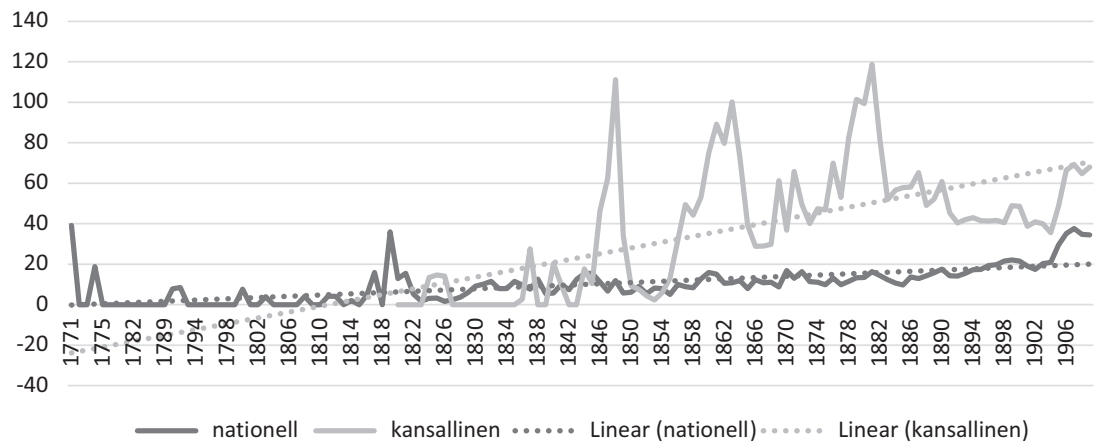

Fig. 3.2 Relative frequency (occurrences per one million words per year) of the lemmas nationell in Swedish and kansallinen in Finnish. Because of very different grammar, the figures are hard to compare across languages, but their rising trend is similar

sentiment was born through a conflation of the language of nationhood and the language of emotions, and perhaps also that this coupling lost some of its appeal in the period after World War I (Fig. 3.2).

Other similar compounds, like national pride or national character, were more frequently used than national sentiment in English, but they also share an increase in frequency in the nineteenth century and a gradual decline in the twentieth. All of these also seem to peak in times of war, which might have to do with their applicability to military rhetoric. ${ }^{26}$ However, in the big picture, these particular terms are not the most important for the language of nationhood. Rather, topics relating to national defense, economy, government, and culture dominate. What matters more than individual things being designated as national is the fact that the term national was overall very productive as a modifier in English, Dutch, Swedish, and Finnish in the nineteenth century. This means that it was used to modify more nouns during the course of the century and gradually the national perspective was used to cover an increasing share of political, social, and cultural life. ${ }^{27}$

The growing use of the term national as a modifier is also seen in Fig. 3.2, which shows a gradually rising trend for the lemmas kansallinen and nationell in Finnish and Swedish respectively. As in the case of "national

\footnotetext{
${ }^{26} \mathrm{My}$ interpretation differs slightly from Trencsényi (2011).

${ }^{27}$ Hengchen et al.
} 
sentiment," the Swedish terminology picks up earlier, peaks first in the early1820 s, and then stabilizes from the 1830s onwards. In Finnish, the breakthrough is around the revolution of 1848, but censorship trumped that discourse until it returns to stay in the mid-1850s. This is also the period when kansallistunto and soon after kansallistunne entered the vocabulary in Finnish. At this time, the Swedish-language data is still considerably larger, so there is also less fluctuation in the Swedish, but it is noteworthy that the relative frequency overall is a bit higher for Finnish than for Swedish in the latter half of the century. This partly relates to differences in grammar but based on a reading of the material seems to boil down to the fact that talking about things national became politically more mobilizing in Finnish than in Swedish at this time. During the latter half of the nineteenth century, Finnish society gained many parallel structures in terms of, for example, learned societies, theatres, organizations for civic education for Finnish and Swedish respectively, and at the same time, the language question became gradually ossified, with some people supporting that development and others hoping to bridge relations between the language groups. ${ }^{28}$

While national sentiment was part of the productivity and gradual growth of the vocabulary of nationhood, the discourse around it remained rather modest, but at the same time it is the term that most explicitly links the nation with emotions. To understand how talking about national sentiment fared in the overall development of national imaginaries in the nineteenth century, I have read through a large part of the occurrences of nationalkänsla, kansallistunne, and kansallistunto in newspapers published in Finland. Following the peaks in frequency, I have concentrated on the breakthrough of national sentiment as a figure of thought in the 1820 s, the years around 1860 with a clear politicization of the language question and the entry of national sentiment as a feature in both Swedishlanguage and Finnish-language discourse, and finally on the 1890s as a period in which the language groups were already seen as self-evidently different although most often belonging to the same nation. The examples show that while uses of national sentiment obviously vary also in synchronous sources, we can see a general change toward a collectivistic and less voluntarist conceptualization. Old, conflicting meanings did not disappear completely, as is seldom the case, but in general the language of national sentiment changed to better match a situation in which the Finnish nation was seen as a self-evident historical subject.

${ }^{28}$ See Engman (2016), 176-235. 


\section{An Individualist Notion of National Sentiment}

After the Russo-Swedish War of 1808-1809, and the consequent establishment of a Finnish Grand Duchy within the Russian Empire, a new need to define Finland and Finnishness emerged gradually. Whether Finland could be regarded as a state or a nation provided central topics for assessing the maturity and future development of the country. But these issues were also overshadowed by much uncertainty regarding Finland's position as a part of Russia and the increasingly distant possibility of rejoining Sweden. During the 1810 s and 1820 s very few voices were vocal regarding Finland's nationhood or statehood, but, toward mid-century, defining those Finnish categories became goals that guided much of domestic politics. ${ }^{29}$

One of the first voices to both theoretically and polemically put forward new ideas about Finnish nationality belonged to Adolf Ivar Arwidsson (1791-1858), a historian and publicist active at the Academy in Turku, but exiled to Stockholm in 1823 due to his politically radical writings. He belonged to a group of young intellectuals, in hindsight dubbed the Turku romantics, who quite broadly engaged in introducing new tenets of the literary romantic style, including individualistic expressions of the self, political activism for freedom of print, and Herderian notions of nationality into Finnish academic discourse. ${ }^{30}$ Despite the broad interests of Arwidsson, his later reputation focuses on the role he played as an early leader of a Finnish national movement and he is often described as a "national awakener" ("kansallinen herättäjä"). ${ }^{31}$ However, the later descriptions of

${ }^{29}$ Jussi Kurunmäki \& Jani Marjanen, "Catching up through Comparison: The Making of Finland as a Political Unit, 1809-1863," Time and Society (2021), https://doi. org/10.1177/0961463X21990349; Tuija Pulkkinen, "Valtio," in Käsitteet liikkeessä: Suomen poliittisen kulttuurin käsitehistoria, ed. by Matti Hyvärinen et al. (Tampere: Vastapaino, 2003), 213-55; Osmo Jussila, Maakunnasta valtioksi: Suomen valtion synty (Porvoo: WSOY, 1987); Aira Kemiläinen, "Nation'-sana ja Porvoon valtiopäivien merkitys," Historiallinen Aikakauskirja 63:3 (1964), 289-304; Matti Klinge, Finlands historia. 3 (Esbo: Schildt, 1996).

${ }^{30}$ Werner Söderhjelm, Åboromantiken och dess samband med utlündska idéströmningar, ed. by Åbo akademi-kommitté 2 (Helsingfors: Schildt, 1915); Łukasz Sommer, "A Step Away from Herder: Turku Romantics and the Question of National Language," The Slavonic and East European Review 90:1 (2012), 1-32, https://doi.org/10.5699/slaveasteurorev2.90.1.0001

${ }^{31}$ Johanna Wassholm, "Att skapa och reproducera minnet av. en nationell storman: A.I. Arwidsson (1791-1858) i storfurstendömet Finlands historiekultur på 1800-talet," Scandia 83:1 (2017), 43-67. 
Arwidsson were formulated in an era during which the thinking about Finnish nationality was much more self-evident than in Arwidsson's own time. When Arwidsson wrote about nationality and language, he couched his ideas in an individualistic notion of self-realization, which foregrounded active choices made by Finns to promote the shaping of a national culture. In this, he was heavily influenced by Herder, who, like Arwidsson, wrote about Nationalgefühl as a telos to be reached in the future. ${ }^{32}$

In an essay on Finnish as a national language that was published as a serial over many issues of Åbo Morgonblad, Arwidsson lamented how it "cannot be expected that a national sentiment towards the mother tongue should be awakened anytime soon" and, further, that it is not likely that "parents and educators would be convinced regarding this topic, which they may not even have reflected upon." ${ }^{33}$ Overall, Arwidsson argued for the elevation of the Finnish language, and as he did that he can be placed in what could be called a constructivist notion of nationhood, in which individuals need to find within them a national sentiment that allows them to promote Finnishness. ${ }^{34} \mathrm{He}$ himself wrote in Swedish and assumed that his audience could read Swedish, but expected that Finnish would be transformed into a language of learning, politics, and culture. National sentiment was a quality that related to the individual and indicated a kind of promise for the future. In the terms of Reinhart Koselleck, it was temporalized and had a clear future orientation. ${ }^{35}$

Arwidsson was well aware that national sentiment or the promoting of Finnish as a national language was not something that would come about naturally but needed active measures and performative deeds. In discussing the role of spoken Finnish, he lamented how people with Finnish as their first language had to switch to Swedish in order to be taken seriously among the educated part of the population. They had to lose their accent and if they were to speak Finnish, "their real mother tongue," they needed to deploy a Swedish accent. ${ }^{36}$

${ }^{32}$ Johann Gottfried von Herder, Kritische Wälder (Bd. 2. Riga, 1769), 166. On Herder in Finland, see Pertti Karkama, Kadonnutta ibmisyyttä etsimässä. Johdatusta Johann Gottfried Herderin ajatteluun ja herderiläisyyteen Suomessa (Helsinki: SKS, 2007).

${ }_{33}^{3}$ Ábo Morgonblad 2 June 1821, 2. An earlier example of the word nationalkänsla can be found in Mnemosyne 3 November 1819, 2.

${ }^{34}$ For a closer analysis, see Marja Jalava, Minä ja maailmanhenki: Moderni subjekti kristillisidealistisessa kansallisajattelussa ja Rolf Lagerborgin kulttuuriradikalismissa n. 1800-1914 (Helsinki: SKS, 2005).

${ }^{35}$ Koselleck (1972).

${ }^{36}$ Åbo Morgonblad 24 March 1821, 4. 
Arwidsson cannot be regarded as representing any kind of general attitude in Finland at this time. His political radicalism and Herderian language philosophy were singular. Still, the notion of national sentiment as something that needed to be awoken among each and every one individually, was not unique. For instance, in 1836, Helsingfors Morgonblad advertised a book comprised of printed plates and titled "Swedish memories" (Svenska minnen) with the aim of animating the readers' memories and "speaking to each and everyone's national sentiment." 37 The book was obviously primarily meant for Swedes, but it seems that there was also a market for it in Finland as the advertisement was published several times, and it seems that the remark about national sentiment either did not bother anyone or the notion itself was flexible.

Overall, newspapers published in Sweden also circulated to a high degree in Finland, and it is clear that they were influential in introducing new political vocabulary to the eastern side of the Gulf of Bothnia. One of the very few comprehensive descriptions of how national sentiment might have been felt and performed, can be found in the Stockholm newspaper Aftonbladet. It published an article titled "On national sentiment" ("Om Nationalkänslan") which recapitulates a meeting at the house of nobility in Stockholm, during which count David Fredrik Frölich had argued that Sweden could no longer stand up to Russia's might. ${ }^{38}$ It is impossible to assess its influence in Finland, but the article must have found a readership in Finland as Russo-Swedish relations were at the heart of Finnish affairs. Frölich stood for a liberal position within the Noble Estate and during his political career advocated a kind of utilitarianism in international politics. ${ }^{39}$

Frölich's statement must be understood against the background of tensions in international politics. Uprisings in Poland had recently been crushed by Russian imperial interference, and many Swedes saw this as a model for how Russia would also react in Finland, that is, in former Swedish territory. Reconquering Finland was not at all on the agenda of King Charles John, but for many Swedes letting go of the idea of reconquering old Swedish domains would have meant admitting that Sweden's period of greatness was in the past. In the Swedish press, revanchist echoes

${ }^{37}$ Helsingfors Morgonblad 19 August 1836, 3.

${ }^{38}$ Aftonbladet 15 April 1831.

${ }^{39}$ Sven Eriksson, "David F Frölich," in Svenskt biografiskt lexikon 16 (Stockholm: Bonnier, 1964), 636, https://sok.riksarkivet.se/sbl/artikel/14567 
were common. ${ }^{40}$ At this time, the alliance between Russia and Sweden from 1812 had ended, which opened up public interest in Finnish affairs in Sweden (partly fueled by Finnish authors who crossed the border). ${ }^{41}$

According to Aftonbladet, Frölich was not even allowed to finish his statement before the audience started objecting by stamping their feet, protesting, and even citing Esaias Tegnér's poem "Svea" from 1811. For the author, this was an example of a national sentiment so strong among the participants that they had to react to the pejorative remarks concerning Sweden's might. ${ }^{42}$ Here, national sentiment comes across as feelings of being hurt, as pride that requires defending. "Svea," which refers to Sweden, had been authored right after the Russo-Swedish war of 1808-1809 and had become a symbol for Swedish patriotism after the loss of large parts of its land area. A reworked version of the poem from 1812 (after the alliance between Karl Johan Bernadotte and Alexander I) included a section that talked about "reconquering Finland within Sweden's borders" as a call to develop the economy and culture of Sweden within its decimated area. ${ }^{43}$ The report does not tell us which parts of "Svea" were recited, but it is apparent that the poem was a sort of antidote to hurt national pride.

Later in the same article, national sentiment is described as something that is inherent to the Swedes. It is the Swedish people who have a national sentiment and that feeling is based on historical experiences:

"The national sentiment of the Swedish people and its state of mind in relation to Russia's politics and government is also something that deserves to be the subject of everyone's 'considerations," the article wrote. It also argued that "Russia cannot complain about a national sentiment among a free people." ${ }^{\prime 4}$

${ }^{40}$ Henrik Edgren, Publicitet för medborgsmannavett: Det nationellt svenska $i$ Stockholmstidningar 1810-1831 (Uppsala: Acta Universitatis Upsaliensis, 2005), http://urn. kb.se/resolve? urn=urn:nbn:se:uu:diva-5773

${ }^{41}$ Lolo Krusius-Ahrenberg, "Finland och den svensk-ryska allianspolitiken intill 1830/31 års polska revolution," Historiska och litteraturhistoriska studier 21-22 (1946), 153-346.

${ }^{42}$ Aftonbladet 15 April 1831.

${ }^{43}$ Esaias Tegnér, "Svea," in Essaias Tegnérs Samlade Dikter II, 1809-1816, ed. by Fredrik Böök \& Åke K. G. Lundquist (Lund: Tegnérsamfundet, 1968), 66; Jani Marjanen, Den ekonomiska patriotismens uppgång och fall: Finska hushållningssällskapet i europeisk, svensk och finsk kontext 1720-1840 (Helsinki: Helsingin yliopisto, 2013), 143.

${ }^{44}$ Aftonbladet 15 April 1831, 2-3. 
What is interesting in Aftonbladet's article, is the tension between collectively shared sentiment, and individually felt indignation in an almost visceral reaction to a speech. In the latter quote it seems that national sentiment is something that all Swedes share, whereas in the reaction to Frölich's speech, it is individuals in the crowd that experience indignation, stamp their feet, and recite patriotic poetry. It seems that this type of vagueness in the meaning of the term national sentiment often escaped contemporaries and that it was used in a rather liberal way. However, going through examples of its use in Finnish newspapers suggests that instances in which national sentiment was understood as belonging to the individual were much fewer than those emphasizing the collective. The examples which meant a sentiment for the nation, not the sentiment of the nation, appeared in the examples from Arwidsson and in Helsingfors Morgonblad, but became proportionately fewer later in the century.

\section{From an Aspirational National Sentiment to National Awakening}

The elevation of the Finnish language was very rapid, with a considerable expansion of new abstract vocabulary, new venues for publication, and a conscious, but still conflicted, campaign to promote Finnish as a language that could be used for educated discourse and governing a state. ${ }^{45}$ This obviously also changed how the language question was framed and how national sentiment related to it. From the 1860s onwards, the language question was not only about promoting Finnish, but was often also understood as an actual struggle between Finnish and Swedish as state-bearing languages. One of the first culmination points of this struggle was a debate between the philosopher, journalist, and leader of the Finnish-language movement, Johan Vilhelm Snellman, and the journalist, August Schauman, about language and nationhood in 1859-1860. Again, the debate was conducted solely in Swedish, but at this time Finnish had a much more established position in public life, and the starting point for the debate was the fear that Swedish would lose its position as a state-bearing language in Finland. ${ }^{46}$

More specifically, the debate revolved around the question of whether a nation could be based on two languages or was confined to only one.

\footnotetext{
${ }^{45}$ See Huumo, Laitinen \& Paloposki (2004).

${ }^{46}$ Jussi Kurunmäki, "Kan en nation byggas på politisk vilja? Debatten mellan J. V. Snellman och August Schauman 1859-1860," Historisk tidskrift för Finland 92:1 (2007), 63-89.
} 
Schauman represented a constitutional and liberal position that sought to defend Finnish bilingualism by referring to examples from Switzerland and the United States of America but was also committed to the process of cultivating the Finnish nation. Snellman, representing the Finnishlanguage movement (the Fennomans), attacked Schauman and argued for a future monolingual nation. ${ }^{47}$ In this debate, both authors touched upon the issue of national sentiment. Snellman, who famously talked of one nation, one language, did this directly by stating that "nowhere in the world $[\ldots]$ can you encounter a sense of unity before the different languages have converged into a common language. This is evidenced by the national sentiment becoming one." 48 Schauman replied that "humans of different tribes and languages can come together and feel that they form one people, one nation, without one or the other tribe having to discard or suppress the other." ${ }^{49}$ In a later discussion in 1863, Schauman returned to the issue of national sentiment in writing against a Finnish pledge of allegiance to Russia and Alexander II. He stressed that the pledges (addresser) were "a sign of Russian national sentiment. We Finns also have a national sentiment, but it is Finnish [...] We know our own nation; we do not count as belonging to the Russian nation, we will never do that. What fires Russian national sentiment, leaves ours cold; what violates our national sentiment, does not hurt the Russian one." 50

Compared with Arwidsson's notion of national sentiment, Snellman had adopted a much more collectivistic meaning for the term, although he in general had an individualistic notion of citizens' role in the state. ${ }^{51}$ For him, national sentiment was not about sentiment for the nation, but of the nation. There are similarities too, as Snellman's national sentiment was also aspirational, something that materialized only after the nation was united under one language. In Snellman's reasoning, nationhood was tied to language and sentiments and literature were results of that common

${ }^{47}$ Kurunmäki (2007); Thiodolf Rein, Juhana Vilhelm Snellmanin elämä 1-2, vol. 2., rev. ed. (Helsinki: Otava, 1904), 276-80.

${ }^{48}$ Johan Vilhelm Snellman, Samlade arbeten. 9, 1859-1860 (Helsingfors: Statsrådets kansli, 1997), 16; See also Kurunmäki (2007), 75.

${ }^{49}$ [Schauman], Papperslyktan 4 April 1859, 106. See Kurunmäki (2007), 75.

${ }^{50}$ Helsingfors Tidningar 17 June 1963, 2. See also Jens Grandell, Från ett årtionde $i$ Finland: August Schauman, republikanism och liberalism 1855-1865 (Helsingfors: Finska Vetenskaps-Societeten, 2020), 210.

${ }^{51}$ For Snellman's individualism, see Tuija Pulkkinen, Valtio ja vapaus (Helsinki: Tutkijaliitto, 1989). 
language. Accordingly, Norway did not have a proper national literature or sentiment nor did the United States of America, as their literary canons were, according to Snellman, in effect written in foreign languages, Danish and English respectively. ${ }^{52}$ Similarly, Finland did not yet possess nationality, but needed to develop one through linguistic unity. Schauman, on the other hand, only wrote about the feeling of belonging to the same people, which leaves the degree of collectivity more open in the first quote, but in the second passage from 1863 his notion of national sentiment is definitely tied to the Finnish nation as a collective. Schauman's notion is more flexible and diverse than that of Snellman, but also for him it was paramount that there was one nation and that the people felt that they belonged to it. In this sense Schauman's notion of national sentiment did not carry that forward-looking aspirational aspect that was present in Arwidsson's individualistic notion and Snellman's collectivist notion. Rather, national sentiment was inherent in the nation.

Snellman can be argued to be the most influential political and philosophical leader of his generation. He was widely read in his time and during that time he was already the object of a conscious process of staging him as a national leader. ${ }^{53}$ Still, in many ways his sophisticated Hegelinspired thoughts about Finland as a state and nation did not trickle down without mutating. The project of promoting Finnish-language culture advanced, but Snellman's conscious construction of Finnishness became less relevant as the Fennoman position grew more confident and was after the 1870s more often than not expressed in Finnish rather than Swedish.

The so-called awakening of Finnish national sentiment was often associated with Snellman, ${ }^{54}$ but in later in the century it was not so important to emphasize the aspirational aspect of feeling the nation. Rather, it was evident that things had already changed as "language obstacles are becoming void, and national sentiment has by and large developed to a higher level." 55 At this point it also became logical to search for national sentiment in an earlier time. For instance, Uusi Suometar reported in 1876 on a speech by Rietrik Polén, a journalist and the first person to defend a Finnish-language doctoral thesis (in 1858), in which he argued that

${ }^{52}$ Rein (1904), 280.

${ }^{53}$ For the staging of Snellman as a leader, see Marja Jalava, J. V. Snellman: Mies ja suurmies (Helsinki: Tammi, 2006); See also Mikko Lahtinen, Snellmanin Suomi (Tampere: Vastapaino, 2006).

${ }^{54}$ See for instance, Uusi Suometar 9 May 1877, 1.

${ }^{55}$ Ilmarinen 24 March 1871, 2. 
Henrik Gabriel Porthan (1739-1804) ought to be seen as the "father of Finnish history and national sentiment." ${ }^{56}$ While Snellman had some twenty-six years previously projected the rise of national sentiment into the future, Rietrik Polén now postulated it for the late eighteenth century. A longer history made for a more prestigious existence, but also lost sight of the impressively fast mobilization of the advancement of Finnishlanguage culture.

Even more influential than Polén was Georg Forsman who used the pen name Yrjö Koskinen, by which he is generally known. Koskinen was seminal for envisioning a history of the Finnish people already before 1809. Unlike Arwidsson, Snellman, or his fellow historian, Zacharias Topelius, Koskinen postulated the Finnish people and nation much further back in time. ${ }^{57}$ In his seminal book on the history of the Finnish people, he even claimed that the Finns' "national self esteem" (kansallistunto) was still strong in the seventeenth century, but later weakened. ${ }^{58}$ In Koskinen's historiography, the Finns had a glorious national past to which the people had recently awoken again. National sentiment or self-esteem (the two were often conflated) had a perennial quality, but could vary in strength. Once this view got more dominant, it also meant that national sentiment was no longer an issue to discuss from a theoretical point of view.

\section{National Sentiment and Ethnic Tensions IN THE RUSSIAN EMPIRE}

Toward the end of the century, it was more common to see national sentiment used in conjunction with ethnic tensions in imperial contexts. At this time most of the newspapers that mention national sentiment relate it either to the language question in Finland, other ethnic tensions in the Russian empire, or to the issue of Schleswig and Holstein. ${ }^{59}$ As we saw from Fig. 3.1, Finnish-language newspapers had started writing about national sentiment using the words kansallistunne and kansallistunto, with the former as a clearer link to the Swedish word nationalkänsla, and

\footnotetext{
${ }^{56}$ Unsi Suometar 4 October 1876, 2.

${ }^{57}$ For Koskinen and Topelius, see Pertti Haapala's chapter in this volume.

${ }^{58}$ Yrjö Koskinen, Oppikirja Suomen kansan historiassa (Helsinki: SKS, 1869), 243.

${ }^{59}$ For Schleswig and Holstein, see, e.g., Helsingfors Dagblad 5 November 1864, 1; Norra Posten 20 February 1897, 4.
} 
overall it seems that the Finnish-language discourse on national sentiment became more important. By the 1880s the terms had clearly become lexicalized and can be seen as commonly held.

Many examples talk about national sentiment in conjunction with hurt feelings, and in that sense they link to August Schauman's use of the term in the 1860s. In the newspaper Nya Pressen, we find an article discussing the so-called postal question as an example of indignation. The paper wrote how Russian travelers in Finland were not allowed to use Russian stamps for their correspondence and that it was "offensive to Russian national sentiment" that Russian stamps were not valid in all parts of the Russian empire. While the paper understands this practical problem as "we Finns ourselves have a rather fragile national sentiment," it still argues that the foundations of Finnish autonomy cannot be sacrificed due to the "nationalism of a few Russian travelers and their convenience." 60

The idea of a hurt Russian national sentiment is expressed quite a few times in the 1890s, often in conjunction with the postal question, which was at the time one of the symbolically laden political issues with regard to Finland's position in the Russian empire. ${ }^{61}$ In this particular example, the interesting thing is that a link was made between national sentiment and nationalism in Russia as if they were merged. It seems, however, that it was more common to juxtapose the two, so that national sentiment was something positive, whereas nationalism was used as a negative label for others. The paper Wiipuri, for instance, noted the negative use of nationalism in Finnish discourse: "When Swedishness [the party] brags pompously, that is not 'nationalism,' but when Finnishness [the party] demands natural rights for proper labor, that is fanatic national thinking." On the same page, but in a different article, the paper reported on "the importance of a Finnish national sentiment" putting the program of the Finnish party into practice. ${ }^{62}$

Debates involved with national sentiment also crossed the language divide. Some years earlier, when the Swedish-minded socialist author, Arwid Mörne, lamented that the Swedish-speaking population was decreasing at the cost of Finnish speakers, he argued that "Whenever we [Swedish speakers] note that national sentiment in a particular region or a particular segment of our Swedish population is faltering, we must make

\footnotetext{
${ }^{60}$ Nya Pressen 11 January 1891, 1.

${ }^{61}$ For instance, Valvoja 1 February 1899, 77.

${ }^{62}$ Wiipuri 14 November 1906, 3rd circulation, 3.
} 
clear to ourselves where the reason for the weakness of the national sentiment lies." ${ }^{63}$ Several Finnish-language papers commented on the text, ${ }^{64}$ the paper Uusimaa being the boldest one in its interpretation. In a remarkable rhetorical move, it stated that Mörne had admitted to a lower degree of national sentiment among Swedish speakers than among Finnish speakers, and further claimed that the rescue of Swedish national sentiment in Finland did not lie in old Swedish customs or history, but rather in adopting a Finnish past. Swedish speakers could keep their language, as long as they strengthened their national sentiment as a part of proper Finnish nationhood. ${ }^{65}$ Like Snellman, the paper demanded unity, but, like Schauman, it also allowed for national sentiment to be bilingual.

The language question remained at the heart of discussions about national sentiment, but it seems, based on a selection of examples from different types of newspapers, that Fennomans, Svekomans, liberals, and socialists all agreed on a core meaning of it in the 1890s and early-1900s. National sentiment had become collectivized and it had lost its aspirational character, but it could be hurt and its degree could be measured. Political and emotional mobilization could perhaps not rely on the idea of awakening a future national sentiment, but the idea of having to defend injured feelings of national belonging did play a role in political discourse.

\section{Conclusion}

The historical transformation of national sentiment includes a shift from an individualistic and even voluntarist notion to a collectivist and less flexible understanding of it. There are some continuities embedded in this transformation, as earlier meanings could resurface in later debates, but in general the pattern is clear: once the nation had become something that most Finns regarded as a reality and the language struggle had gained parties that were more or less set, a voluntarist notion of national sentiment became nearly obsolete. While concrete descriptions of national sentiment as bodily reactions and cultural performances are very uncommon in newspaper material of the time in the first place, it seems that the

\footnotetext{
${ }^{63}$ Arwid Mörne, "Förfinskningen av. vår svenska landsbygd och folkbildningsarbetet därstädes," Finsk tidskrift 49:4 (October 1900), 244.

${ }^{64}$ See Arvid Mörne, "Svenskhet och patriotism," Finsk tidskrift 49:6 (December 1900), 451. The mentioned papers are Päivälehti 25 October 1900; Uusi Suometar 27 October 1900; Uusimaa 31 October 1900; Valvoja November 1900.

${ }^{65}$ Unsimaa 31 October 1900, 1.
} 
collectivization of the idea of national sentiment made these types of descriptions even less likely. Rather, national sentiment was related to concrete emotions only through the claims of strong or lacking national sentiment in one or the other language group. This is clear in the examples of Arwid Mörne and Uusimaa from the year 1900. Feelings did not lie in the national sentiment itself, but in how it was used rhetorically in the texts.

Bearing in mind this transformation of national sentiment, we have to reconsider the long history of nationalism and nation building in Finland that emphasizes a continuity from late eighteenth-century interest in the Finnish language and folklore by Henrik Gabriel Porthan and his colleagues at the Academy in Turku, to the great national leaders, A. I. Arwidsson and J. V. Snellman and their associates, and then finally to mass mobilization of the Finnish party in the latter half of the nineteenth century. ${ }^{66}$ While it would be wrong to deny a continuity of sorts, it is important to note that the future-oriented national sentiment of Arwidsson and Snellman was significantly transformed in later use. The kind of openness to the issue of nationality that they represented was not possible later on. ${ }^{67}$ Further, and more importantly, the continuity from Porthan, Arwidsson, and Snellman to late nineteenth-century authors was made considerably stronger in the late nineteenth century when the issue of nationality was already seen as self-evident. At this point creating a history for the national movement served the purpose of making Finnish nationhood more stable.

${ }^{66}$ An influential example of this continuity is in Miroslav Hroch, Die Vorkämpfer der nationalen Bewegung bei den kleinen Völkern Europas: Eine vergleichende Analyse zur gesellschaftlichen Schichtung der patriotischen Gruppen (Prague: Univ. Karlova, 1968).

${ }^{67}$ See also Reetta Eiranen's chapter in this book. 
Open Access This chapter is licensed under the terms of the Creative Commons Attribution 4.0 International License (http://creativecommons.org/licenses/ by $/ 4.0 /)$, which permits use, sharing, adaptation, distribution and reproduction in any medium or format, as long as you give appropriate credit to the original author(s) and the source, provide a link to the Creative Commons licence and indicate if changes were made.

The images or other third party material in this chapter are included in the chapter's Creative Commons licence, unless indicated otherwise in a credit line to the material. If material is not included in the chapter's Creative Commons licence and your intended use is not permitted by statutory regulation or exceeds the permitted use, you will need to obtain permission directly from the copyright holder. 